\title{
Lower Sinemurian foraminifera and Ostracoda from two fissure deposits in the Eastern Mendips (Somerset, England)
}

\author{
PHILIP COPESTAKE \\ British National Oil Corporation, Stratigraphic Laboratory, 220 St. Vincent Street, Glasgow, G2 5LJ, Scotland
}

\begin{abstract}
Foraminifera and Ostracoda are recorded from two Mesozoic fissures in the Eastern Mendips (Cloford and Holwell). The microfaunas are indicative of the Early Sinemurian (bucklandi-semicostatum Zones), and provide the first evidence for the former presence of sediments of this age on the Mendip "swell".
\end{abstract}

\section{INTRODUCTION}

The Carboniferous Limestone of the MendipsGlamorgan region is unique in containing numerous vertical fissures filled with a complex array of sediments ranging in age from $\mathrm{Rhaetian}$ to Bathonian. The fissures are generally truncated by the pre-Inferior Oolite (Bajocian) unconformity surface (Fig. 1). Published accounts (e.g. Moore, 1867; Robinson, 1957; Savage \& Waldman, 1966) have concentrated on those fissures with Rhaetian sedimentary infills which contain a diversity of early mammal remains unknown from other types of deposit. Recent research largely by Mr. C.T.J. Copp, however, has shown that many fissures contain ? Hettangian, Upper Sinemurian, Pliensbachian and also rare Toarcian (Junction Bed) and possibly Bathonian (Fuller's Earth) marine sediments.

The fissures are considered (C.T.J. Copp, pers. comm.) to represent old joint planes, or less frequently, faults (as in the case of Holwell fissure HBVII) which opened up during phases of intra-Early Mesozoic folding. The arrangement and orientation of the fissure lithologies suggest that the sediments were sucked down from their bedded position upon the top of the Carboniferous Limestone which formed the sea floor. Most of the fissure sediments are thus not neptunian dykes (i.e. passive openings in the sea floor, gradually filling with in situ sediment) as previously thought (e.g. Robinson, 1957), but are much more dynamic and tectonically controlled. The major fissures (e.g. those studied here) have an east-west trend parallel to the axial trend of the Mendip pericline, while smaller fissures tend to follow the regional joint pattern.

Two siltstones from separate fissures at Cloford and Holwell were sampled by the author in an attempt to obtain microfaunal evidence for their age. The microfaunas are described in this paper. Macrofaunas from the fissures are generally very sparse with ammonites occurring only very rarely, so that any evidence of age is valuable.

The sampling localities are as follows:
1. Cloford quarry - one third of a mile WNW of Cloford, Somerset, south of A361. Nat. Grid Ref: ST 717445. One sample of brown, friable siltstone from centre of fissure CXIV (Copp, MS) in north west corner of quarry. This quarry contains twenty-one fissures, these being the best preserved examples in Britain (Figs. 2, 3).

2. Holwell quarry - southernmost pit in quarry complex adjacent to Bear Inn, Holwell, immediately south of A 361. Nat. Grid Ref: ST 724449. This quarry, immediately west of Moore's (1867) "Microlestes" quarry, equates with quarry Q3 of Savage (1977, fig. 8) (quarry $\mathrm{HB}$ of Copp [MS]). One sample of grey siltstone from fissure $\mathrm{HBVII} / \mathrm{HBX}$, along south quarry wall.

\section{BIOSTRATIGRAPHY}

1. Cloford. A rich and diverse foraminiferal fauna was recovered from the Cloford sample (see Table 1), dominated numerically by the Lingulina tenera (Bornemann) plexus and Planularia protracta (Bornemann) gr. Short ranging index species are absent, but considerations of the total ranges of the taxa and their known acmes in nearby sections (e.g. Hock Cliff and Stowell Park Borehole, Gloucestershire, Wilkesley Borehole, Cheshire [author's unpublished data] and Mochras Borehole, Gwynedd [Copestake \& Johnson in press]) enable age deductions to be made for the sample. Most taxa present range at least from Rhaetian or Hettangian to high in the Lower Jurassic, but several exhibit British acmes in the bucklandi and semicostatum Zones of the Lower Sinemurian, i.e. Nodosaria metensis Terquem, Lagena aphela Tappan, Lingulina/Nodosaria cernua (Berthelin), Frondicularia brizaeformis (Bornemann), Dentalina torta Terquem. Others, although again having long total ranges, are not consistently seen in British successions until the bucklandi-semicostatum Zones, namely Vaginulina listi Bornemann, Nodosaria regularis regularis Terquem, Dentalina matutina d'Orbigny and Lingulina tenera 


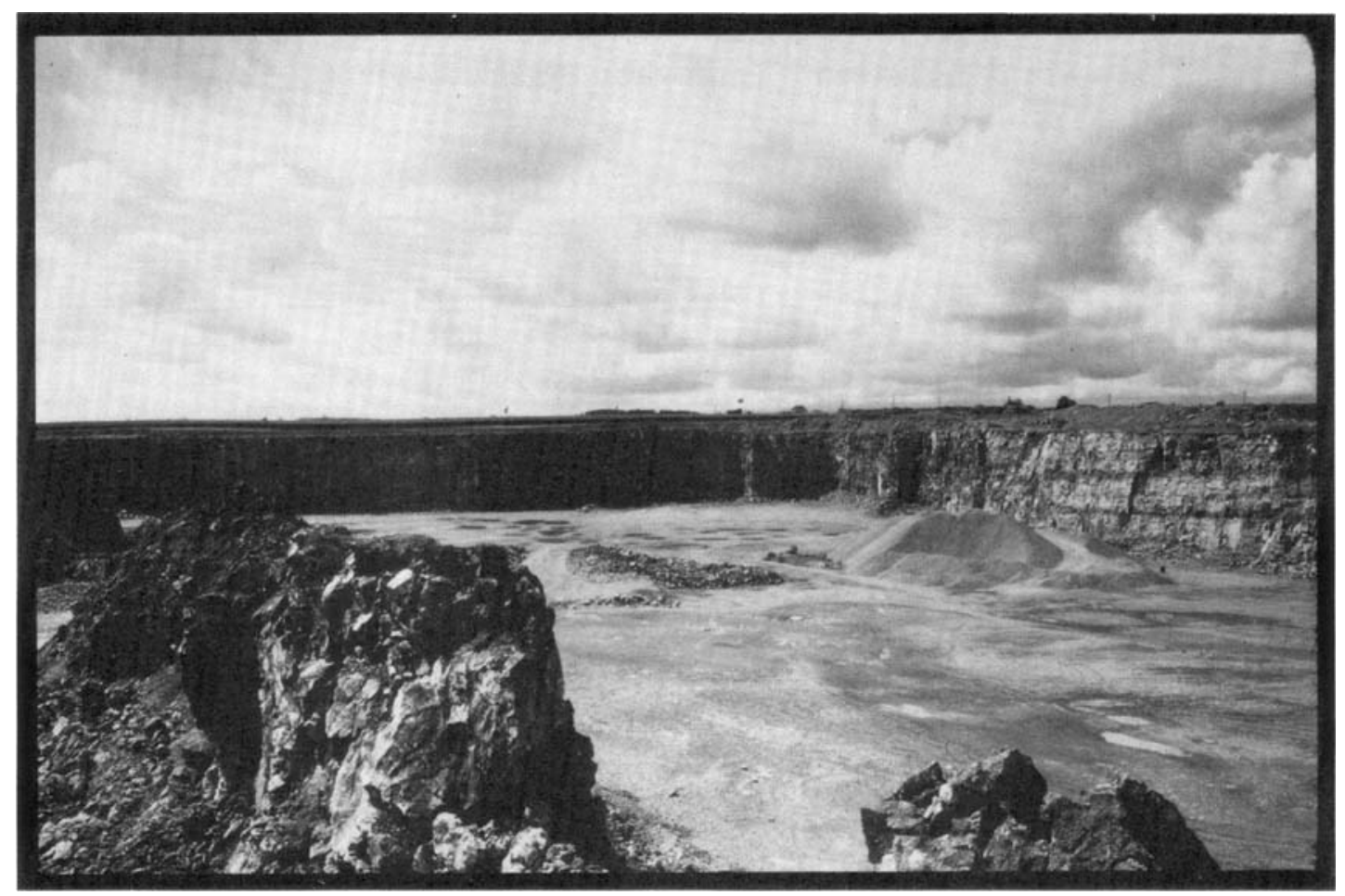

Fig. 1. Westward view of Cloford quarry. Note darker vertical fissures in pale Carboniferous Limestone country rock. Large mass in left foreground represents fissure $\mathrm{CXXI} / \mathrm{CI}$ infill sediments isolated by quarrying (this fissure may link to the east with Holwcll fissure HBVII/HBX discussed herein). Note planar horizontal pre-Upper Inferior Oolite unconformity surface (bored and cncrusted) truncating fissures.

pupa (Terquem). The foraminifera thus strongly suggest an Early Sinemurian (bucklandi-semicostatum Zonc) age. The known British ranges and total ranges of all the species recovered are shown in Table 1.

Ostracoda present in the sample include Carboniferous taxa (probably derived from the fissure walls) plus indeterminate early Mesozoic (? Triassic) cytheraceans (E. Robinson and A.R. Lord, pers. comm.).

2. Holwell. The poor foraminiferal assemblage from this sample contains five species all characteristic of the British bucklandi Zone, e.g. Marginulina prima insignis Franke (acme bucklandi Zone), Lingulina tenera Bornemann form E Barnard (angulata-bucklandi Zones in Mochras Borehole, semicostatum-turneri Zones in Stowcll Park Borehole) and Nodosaria pseudoclaviformis Copestake \& Johnson (bucklandilevesquei Zones in Britain).

Ostracoda are more numerous and, unlike the Cloford suite, are all Lower Jurassic taxa. They are referred to Bairdia molesta Apostolescu (HettangianLower Pliensbachian), Ogmoconchella ellipsoidea (Jones) (planorbis-top bucklandi Zones in Britain according to Lord (1978), but present in semicostatum Zone in Wilkesley Borehole [author's data]) and Ogmoconcha hagenowi Drexler (planorbis-mid turneri
Zones). The age interpretation for this ostracod species association hinges on the upper range limit of O. ellipsoidea. Although present up to the semicostatum Zone (see above), the species is only common as high as the bucklandi Zone (as at Hock Cliff and Wilkesley). The Ostracoda thus support the bucklandi Zone age suggested by the foraminifera but are not precisely confirmative. The known British ranges and total ranges of all the taxa recovered are shown in Table 1.

\section{DISCUSSION}

The two assemblages from similar siltstone lithologies suggest analogous ages of bucklandi-semicostatum Zones (with derived Carboniferous Ostracoda) (Cloford) and bucklandi Zone (Holwell). In view of the dominantly tectonic mode of emplacement of the fissure deposits, the present study provides the first evidence of the former presence of Lower Sinemurian (bucklandisemicostatum Zone) sediments on the Mendip positive area or "swell". The nearest coeval bedded rocks are to the west at Shepton Mallet where they occur in littoral and semi-littoral facies (Moore, 1867) quickly passing to the south into normal offshore Blue Lias facies (e.g. at Cannard's Grave; Donovan, 1958). Lower Sinemurian sediments have not previously been identified in the Mendip fissures. From the Howell fissure (HBVII/HBX) 


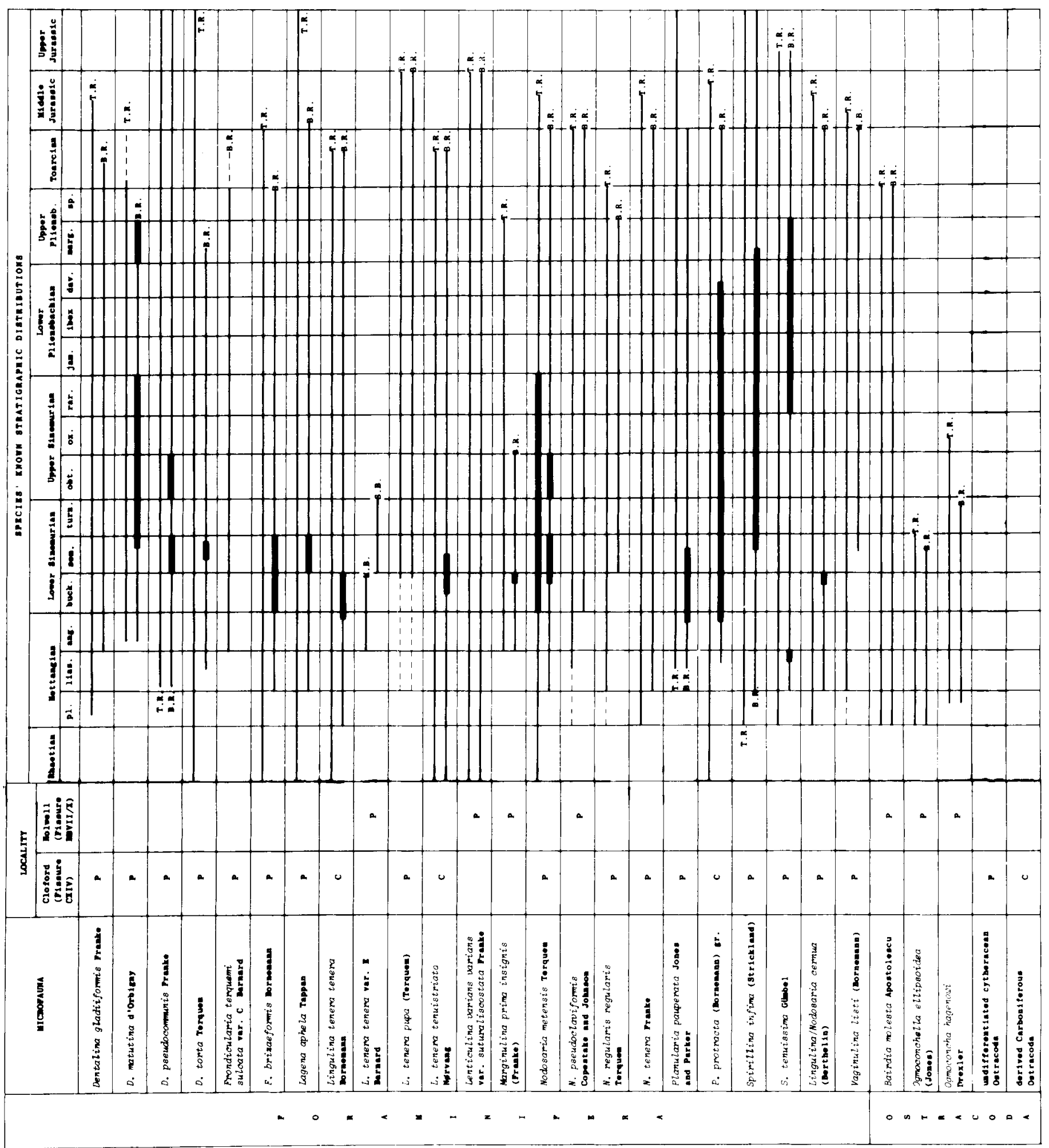

Table 1. Details of Mendip fissure microfaunal assemblages $(T . R .=$ total range, B.R. $=$ British range, M.B. = Mochras Borehole, S.B.= Stowell Park. Borehole, $\mid=$ known range, $\mathbf{I}=$ acme, $=$ possible range, $\mathbf{P}=$ present, $\mathrm{C}=$ common). 


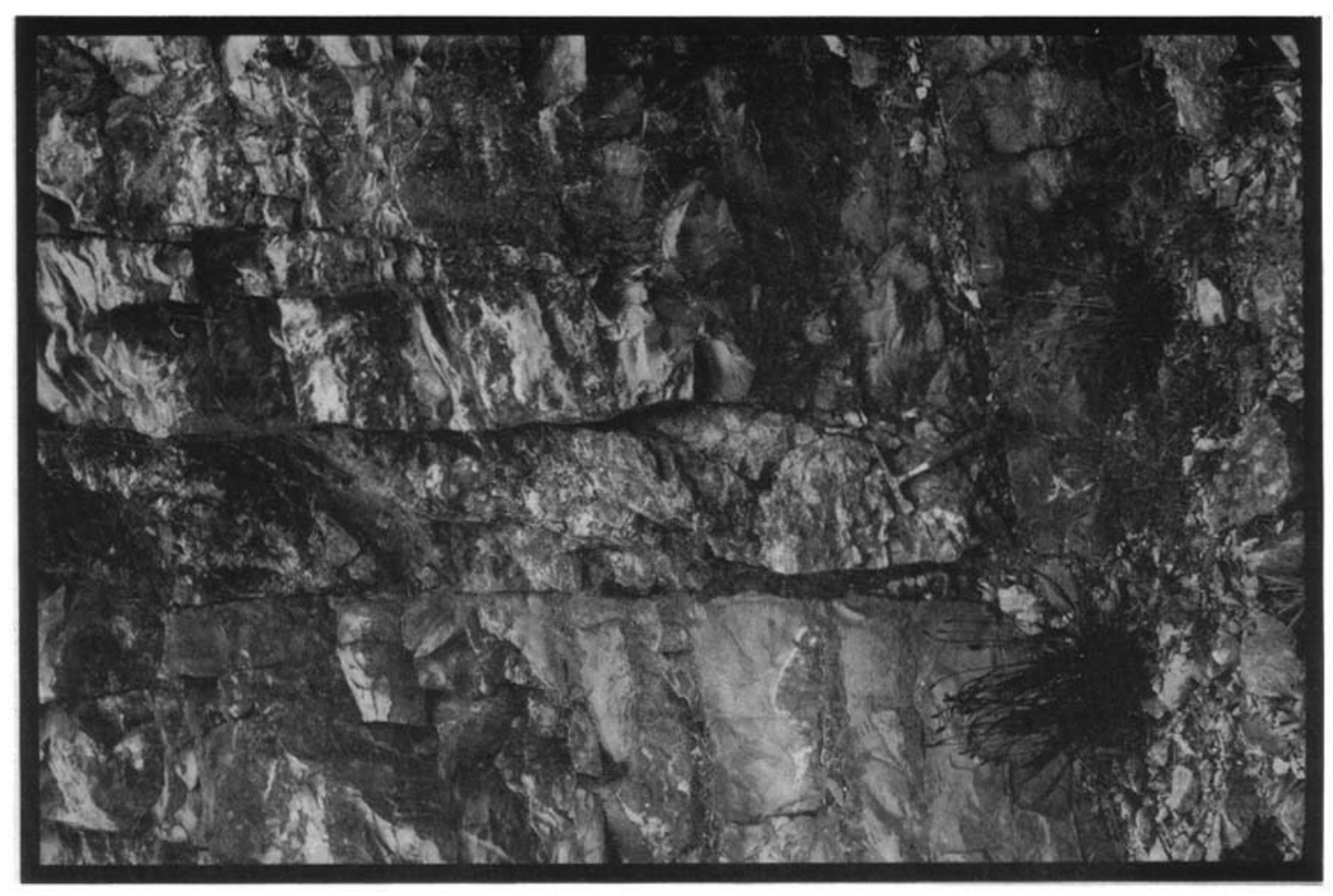

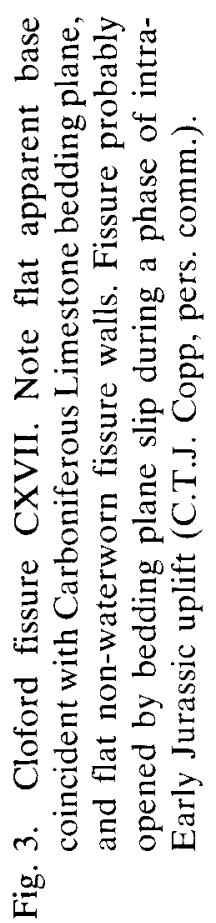

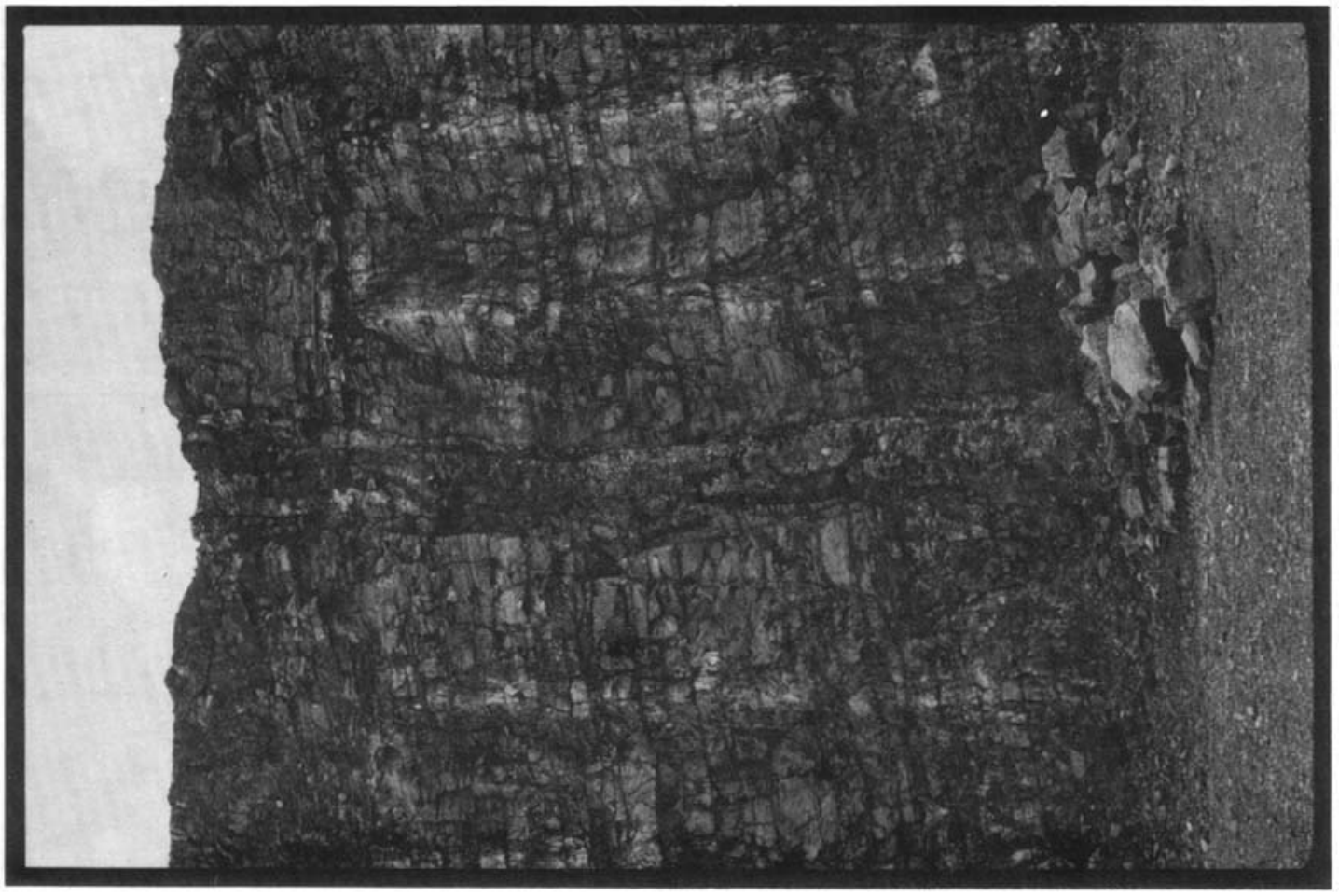

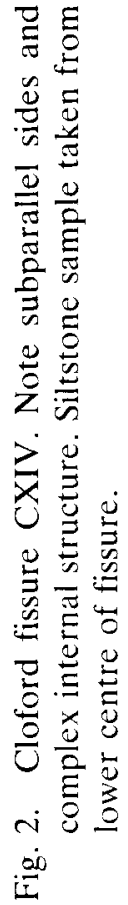


are also recorded Rhaetian sediment, grey bioclastic limestone (probably Late Sinemurian on non-ammonite macrofossil evidence) and greenish clay of possible Pliensbachian age (C.T.J. Copp, MS). The Cloford fissure (CXIV) is known to contain, in addition to the Lower Sinemurian siltstone described above, limestones of probable jamesoni Zone age.

\section{ACKNOWLEDGEMENTS}

The author is grateful to Mr. C.T.J. Copp for guidance in the field and for access to unpublished data and to Drs. A.R. Lord and E. Robinson for identifying the Cloford Ostracoda.

\section{REFERENCES}

Copestake, P. \& Johnson, B. (in press) Lower Jurassic (Hettangian-Toarcian) foraminifera from the Mochas Borehole, North Wales; systematic and biostratigraphical micropalaeontology. Rep. Inst. Geol. Sci.

Donovan, D.T. 1958. The Lower Lias section at Cannard's Grave, Shepton Mallet, Somerset. Proc. Bristol Nat. Soc., 29, 393-398.

Lord, A.R. 1978. The Jurassic Part 1 (HettangianToarcian). In Bate, R. \& Robinson, E. (Eds.). A Stratigraphical index of British Ostracoda. Geol Jour. Spec. Issue No. 8, 189-212, Seel House Press, Liverpool.

Moore, C. 1867. On Abnormal Conditions of Secondary Deposits when connected with the Somersetshire and South Wales Coal-basin. Q. Jl geol. Soc. Lond. 23, 449-568.

Robinson, P.L. 1957. The Mesozoic fissures of the Bristol Channel area and their vertebrate faunas. J. Linn. Soc., London, (Zoo.) 43, 260-282.

Savage, R.J.G. 1977. The Mesozoic strata of the Mendip Hills. In Savage, R.J.G. (Ed.). Geological Excursions in the Bristol District, 85-100. University of Bristol.

Savage, R.J.G. \& Waldman, M. 1966.Oligokyphus from Holwell quarry, Somerset. Proc. Bristol. Nat. Soc. 31, 185-192. 